\title{
A CENA DO MUNDO E A CENA DA VIDA: NOTAS SOBRE TEATRALIDADE, FILOSOFIA E AUTOBIOGRAFIA EM ROUSSEAU
}

Rafael de Araújo e Viana Leite ${ }^{1}$

\begin{abstract}
Resumo:
Trata-se de investigar a articulação entre a teatralidade presente na escrita de Jean-Jacques Rousseau, seu sistema filosófico e a sua autobiografia. Veremos, a partir da análise de textos selecionados, como o teatro e os elementos pertencentes a essa arte não servem apenas como recursos de escrita, mas são empregados como um paradigma caro à reflexão filosófica de Rousseau.
\end{abstract}

Palavras-chave: Rousseau, Teatro, Autobiografia, Filosofia.

\section{THE SCENE OF THE WORLD AND THE SCENE OF LIFE: REMARKS ON THEATRICALITY, PHILOSOPHY AND AUTOBIOGRAPHY IN ROUSSEAU'S THOUGHT}

\begin{abstract}
:
The aim of this paper is to analyze the connection between the theatricality that is found in Rousseau's writings, his philosophical system and his autobiography. We shall see how the theatre and the resources of this art are used not only as a writing strategy but as an important paradigm of his philosophical reflection.
\end{abstract}

Keywords: Rousseau, Theatre, Autobiography, Philosophy.

\begin{abstract}
Dou início a um empreendimento em relação ao qual não houve jamais exemplo e cuja execução não terá em absoluto imitadores. Desejo mostrar aos meus semelhantes um homem em toda a verdade da natureza e serei eu esse homem (ROUSSEAU, Confissões, 1959 t. I, L. I, p. 5).

Dado que o meu nome deve permanecer entre os homens, não desejo que carregue entre eles uma reputação mentirosa. Não desejo que me revistam com virtudes e vícios os quais não possuía, nem que me retratem com delineamentos que não foram os meus (...) prefiro que me conheçam com todos os meus defeitos, e que seja eu mesmo, do que com qualidades forjadas baseadas em um personagem que me é estranho (ROUSSEAU, Esboço das Confissões, 1959, t. I, p. 1153).
\end{abstract}

\footnotetext{
$1 \quad$ Fez graduação, mestrado e doutorado em Filosofia pela UFPR. É membro da ABES XVIII (Associação brasileira de estudos sobre o século XVIII), do GIP Rousseau (Grupo interdisciplinar de pesquisa Jean-Jacques Rousseau) e participa, desde 2009, do Grupo das Luzes - UFPR. Publicou artigos, tradução e resenha em revistas de Filosofia. Atualmente, realiza estágio de pós-doutorado na UFPA (CAPES-PNPD). E-mail: rafael_vianaleite@hotmail.com.
} 
Comecemos este texto com uma afirmação pouco contestável, mas que pode desvelar nosso horizonte de investigação. Apontemos a distância entre a vida, essas coisas verídicas que acontecem com alguém e, de outro lado, o que é da esfera da representação. Esse último registro pode ser identificado a uma peça teatral, pertencente ao que se chamava no século XVIII de poesia dramática. Temos uma oposição quase intransponível entre esses dois campos capaz de colocar a vida no âmbito da realidade e o teatro, arte mimética, como algo que está ligado ao fictício. A representação de um acontecimento, mesmo se tiver algum lastro em elementos reais, pode ser descrita enquanto uma forma de faz de conta, como aprendemos quando criança para melhor separar essas histórias das mentiras com as quais pretendemos nos beneficiar em detrimento dos outros. A poesia dramática pode ser, portanto, identificada a uma imitação, porém não é exatamente mentira quando não há intenção de prejudicar alguém ou de se beneficiar e detrimento dos outros, tal qual lemos na quarta Caminhada dos Devaneios de um caminhante solitário (1959, t. I, p. 1029). É sobre a tensão entre vida e a cena da vida em Jean-Jacques Rousseau que nos deteremos aqui.

É sabido como Rousseau nutriu amor pela cena teatral, mas o modo como a sua reflexão se liga a esse universo não é tão investigado. O que está em jogo para nós é a relação entre a escrita filosófica, a autobiografia e o universo teatral. Meu objetivo não é fazer simplesmente um recenseamento de elementos teatrais presentes na obra do filósofo, mas mostrar a sua articulação com o sistema filosófico e questões autobiográficas. Para realizar esta investigação, ainda preliminar, apontarei em um primeiro momento para usos possíveis do teatro na letra do texto de Rousseau. Em seguida, veremos um exemplo da importância da teatralidade no que diz respeito à formação do seu vocabulário filosófico para, em um último momento, propor a defesa de que nas Confissões, quando Rousseau traça seu retrato, temos elementos suficientes para perceber uma espécie de mise en scène.

Apesar de ser considerado, por vezes, um inimigo do teatro, sua relação com essa arte foi por demais estreita para darmos partida a esta investigação sob os auspícios de uma premissa desse tipo. Foi, com efeito, como músico e autor dramático que um dia ele solicitou entrada na República das letras, tendo composto sete peças, em mais de um gênero. Podemos dizer que o teatro constituiu o terreno onde a ambição literária do jovem aspirante a autor foi cultivada e, já maduro, o célebre filósofo - sintomaticamente - não renegou essas obras, como é verificado em uma carta endereçada ao seu editor, Marc-Michel Rey, datada de 24 de outubro de 1758, ano da publicação da Carta a

\begin{tabular}{|c|c|c|}
\hline Q Rovista Dialectus & Ano 8 n & n. 15 \\
\hline
\end{tabular}


d'Alembert. Nessa correspondência, comenta-se a respeito de um compêndio dos seus escritos no qual figuraria, no primeiro volume, os menos importantes, contendo as peças de teatro (1967, CC, Carta 716). Lembro ainda da composição de uma cena lírica, elogiada por Goethe, chamada de Pigmalião, cuja data é tardia, 1762. No mesmo ano da publicação do Contrato social, portanto, o esforço de Rousseau estava também direcionado para um texto de ordem teatral.

Enquanto viveu em Paris, vale lembrar, era nas salas da Comédie française e da Comédie italienne onde buscava entretenimento e, conforme afirma nas Confissões, nos idos de 1742, recém-chegado à cidade parisiense ele ia aos espetáculos somente duas vezes por semana. Esse número pouco expressivo, conforme o relato, era devido à necessidade de economizar dinheiro, mas tal condição restritiva logo acabou quando Rousseau passou a obter ingressos gratuitos destinados aos autores cujas peças haviam sido aceitas na Comédie italienne (1959, t. I, L. VII, p. 287). Durante dez anos, ele dirá ainda em uma nota do parágrafo 166 da Carta a d'Alembert, frequentou os teatros parisienses nos dias bons e ruins (1967, p. 186).

O que me interessa notar com esse panorama inicial é o fato de que a relação com o teatro teve real importância não só para Rousseau enquanto escritor, mas também para o filósofo, seja do ponto de vista da formação do seu vocabulário quanto da imagem de si apresentada nas Confissões. A investigação da ligação do vocabulário de Rousseau com o âmbito teatral, tema deste artigo, parece ainda por fazer, haja vista o pequeno, mas interessante livro introdutório de André Charrak chamado Le vocabulaire de Rousseau (2002). A ideia da obra é basicamente explicar, a partir de verbetes, os principais termos com os quais o filósofo genebrino se expressa. Em meio a verbetes como "vontade geral", "educação" e "cidadão" não há, surpreendentemente, nenhuma menção a termos como "teatro", "cena" ou "espetáculo". Poder-se-ia, quem sabe, defender tão simplesmente que esses termos não são tão filosóficos como os citados anteriormente. A reflexão de Rousseau, entretanto, se liga ao teatro de modo essencial na medida em que, por exemplo, se vale claramente de um léxico tirado dessa arte para construir tanto um vocabulário filosófico quanto para proceder a uma crítica da sociedade setecentista.

São múltiplas as formas como acontece o empréstimo de elementos teatrais na letra do filósofo genebrino e, neste artigo, não pretendo esgotar as suas ocorrências. As menções diretas aparecem frequentemente em seu horizonte reflexivo, por exemplo, em forma de referências a certos personagens, metáforas e, mais indiretamente, com o

\begin{tabular}{|c|c|c|c|c|}
\hline Q Rovista Dialectus & Ano 8 & n. 15 & Agosto - Dezembro 2019 & p. $268-287$ \\
\hline
\end{tabular}


emprego de recursos de escrita ligados a essa arte. Nota-se, igualmente, o uso do teatro enquanto categoria a partir da qual se pode refletir sobre temas filosóficos, buscar um vocabulário para lhe dar forma, além de ser o registro a partir de onde Rousseau ambienta sua vida.

Nesse sentido, se tomamos em mãos o Livro VI das Confissões podemos notar, por exemplo, a identificação direta do autor com alguma figura teatral. É o que acontece quando Rousseau se reconhece tímido tal qual certo personagem de Marivaux, o Marquês de Legs (1959, t. I, p. 250). Já no Livro IX, a comparação recai sobre o enganado George Dandin, de Molière (1959, t. I, p. 472). Eis o registro escolhido para extrair exemplos com os quais desvela elementos de sua personalidade, mas também de suas ações, algo claramente elucidado quando um episódio de sua vida é referido como se fosse uma cena $(1959$, t. I, L. IV, p. 141). Não temos, nesse caso, menção direta a uma peça, porém algo ainda mais interessante, a explicitação de uma teatralidade que seria própria à sua vida ou que melhor a manifestaria. A mesma coisa acontece quando relata certo episódio, a saber, a anedota da nogueira presente nas Confissões. Em tom de gracejo, Rousseau desafia seu leitor a não tremer durante a leitura dessa horrível tragédia: “Oh vós, leitores curiosos da grande história da nogueira do terraço, escute a horrível tragédia (...) e abstenha-se, se puder, de tremer" (ROUSSEAU, 1959, t. I, L. I, p. 21).

Não nos esqueçamos de que o seu processo de reflexão é descrito, caracteristicamente, como conturbado de modo semelhante à mudança de decoração do palco da ópera italiana (1959, t. I, L. III, p. 113-114). Esses elementos ajudam a montar um quadro de referência a partir do qual podemos entender por qual motivo identificase na segunda metade do século XVIII francês certa teatromania. Entretanto, como a escrita de Rousseau se articula com a teatralidade?

$\mathrm{Se}$ as peças teatrais de sua autoria são hoje pouco lidas, passagens memoráveis de outras obras revelam como é intenso o uso de recursos teatrais enquanto estratégia argumentativa. Para evidenciarmos essa característica, basta tomarmos nas mãos a inflamada prosopopeia de Fabrício, presente no Discurso sobre as ciências e as artes; a emblemática cena do estabelecimento da propriedade, em forma de apóstrofe, na abertura da segunda parte do Discurso sobre a desigualdade ou, ainda, a chamada Iluminação de Vincennes, relatada entre outros textos na Carta a Malesherbes. Sua obra pedagógica Emílio bem poderia, como afirmou Luiz Roberto Salinas Fortes, ser vista como uma peça dramática preenchida por cenas pedagógicas e episódios patéticos, tal

\begin{tabular}{|c|c|c|c|c|}
\hline Q Rovista Dialectus & Ano 8 & n. 15 & Agosto - Dezembro 2019 & p. $268-287$ \\
\hline
\end{tabular}


qual o do charlatão da feira com seu pato magnetizado, além das danças e das pantomimas (1997, p. 24-25 e p. 142). Temos, desse modo, um número expressivo e importante de estratégias discursivas capazes de mostrar como o recurso aos lances teatrais se apresenta frequentemente como desfecho ou introdução aos elementos propriamente teórico-filosóficos.

A antítese manifestada entre "ser" e "parecer" é comumente compreendida como uma perspectiva que norteia a reflexão filosófica de Rousseau desde, ao menos, o Discurso sobre as ciências e as artes, de 1750. Essa oposição propriamente teatral entre "o que é" e o que "parecer ser" é um registro prolífico de onde se deriva outras oposições como "autenticidade" e "alienação" ou "transparência" e "obstáculo"2. O recurso à antítese, vale notar, estratégia muito usada no teatro, aparece em outros momentos da mesma obra, quando se opõe o dourado do cortesão à rusticidade do lavrador, a cidade ao campo, o rico ao pobre ou mesmo quando os atenienses são contrapostos ao povo espartano. Qual é a imagem usada na primeira frase da primeira Parte do chamado primeiro Discurso senão a de um espetáculo?

O recurso ao teatro pode ainda ser o do exemplo erudito. É o que acontece quando, no Livro I do Emílio, de modo a corroborar a maneira pela qual a ama-de-leite seria importante na antiguidade, cita-se o fato de que nas peças de teatro dos antigos normalmente ela é a confidente (2004, p. 40). Mesmo em uma obra científica, como é o caso das Instituições químicas, há lugar para as metáforas teatrais, como se pode ver no Livro 2, Capítulo I, primeiro parágrafo, passo do texto em que a natureza é comparada a um teatro em relação ao qual poucos conseguiriam enxergar o conjunto, arrebatados por aspectos mais marcantes ou acessíveis à sua compreensão. No Livro IV do Emílio falase em "cena do mundo" (ROUSSEAU, 2004, p. 333) e, em seguida, em "palco do mundo" (ROUSSEAU, 2004, p. 335). Em um texto pouco conhecido como o Ensaio sobre os acontecimentos importantes cuja causa secreta foram as mulheres é empregado mais uma vez essa metáfora ao mesmo tempo importante e frequente na letra do autor: ao tratar sobre um tema historiográfico se fala em história do teatro do mundo (1961, t. II, p. 1257-1269). É como se o observador e estudioso da história testemunhasse no palco no qual se estruturam as sociedades o desenrolar do enredo das ações humanas. Aos poucos pode-se perceber como a oposição entre teatro e a vida não fictícia pode se tornar menos firme e categórica do que parecia inicialmente.

2 Refiro-me, respectivamente ao livro de Bronislaw Baczko, Rousseau: solitude e communauté (1974) e ao livro de Jean Starobinski, intitulado Jean-Jacques Rousseau: transparência e obstáculo (2011).

\begin{tabular}{|c|c|c|c|c|}
\hline Qevista Dialectus & Ano 8 & n. 15 & Agosto - Dezembro 2019 & p. $268-287$ \\
\hline
\end{tabular}


O inventário desses usos ajuda a esclarecer como no caso do projeto das Confissões, para apresentar o retrato de um homem em toda a verdade da natureza (1959, t. I, L. I, p. 5), Rousseau solicita surpreendentemente o mundo teatral, isto é, o reino da aparência. O objetivo do empreendimento das Confissões é essencialmente filosófico e explicitado na abertura da obra em uma passagem que nos serviu como epígrafe. Trata-se de manifestar o homem, mas a partir de um eixo específico, mostrá-lo tal como ele é em acordo com a natureza, ou seja, em contraposição ao que é inautêntico, além de expor sua localização histórica, ou seja, contingente e a sua condição, qual seja, única e inimitável ${ }^{3}$. A teatralidade é essencialmente ambígua, pois é passível de ser usada a partir de dois eixos principais: um negativo, sinônimo de dissimulação e outro positivo que se confunde com o espetáculo da autenticidade. Isso acontece por causa do complexo campo semântico desse termo que pode operar tanto em uma mais de uma acepção. Ora, podemos estar diante do belo espetáculo da natureza, tal qual descrito por Saint-Preux diante das montanhas do Valais, na Nova Heloisa (1964, t. II, Primeira Parte, p. 77-78), mas também podemos testemunhar o espetáculo nefasto da injustiça e malignidade, como se lê na sexta Caminhada dos Devaneios de um caminhante solitário (1959, t. I, p. 1057).

Vejamos uma passagem importante na qual a teatralidade aparece de maneira estratégica na letra do texto. A gênese da socialização tal qual proposta no Discurso sobre a desigualdade e no Ensaio sobre a origem das línguas é, não por coincidência, uma cena. Esse aspecto evidencia como o teatro é pensado enquanto um referente para a reflexão filosófica. Efetivamente, toda a descrição das chamadas festas primitivas possui um registro semântico marcado pela teatralidade. Essas festas, ritmadas pelo canto, dança e jogos de sedução em torno das cabanas, de uma fogueira ou de uma grande árvore se inserem claramente no que podemos chamar de espetáculo de socialização. Essa descrição hipotética é fundamental para entendermos como se dá a cisão entre ser e parecer, momento em que foi preciso se mostrar outro que não o que se era. Segundo a perspectiva de Rousseau, o início do estreitamento dos laços sociais incita o surgimento de paixões factícias como amor e a inveja, além de artes como o canto, a dança e a poesia, participantes essenciais do mundo teatral e nascidos da ociosidade, filhos da diversão (ROUSSEAU, 1964, t. III, p. 169).

Ann Hartle analisa essa passagem na obra El sujeto moderno en las 'Confessiones' de Rousseau: una respuesta a San Agustín (1989, p. 26-27).

\begin{tabular}{|c|c|c|c|c|}
\hline Q Rovista Dialectus & Ano 8 & n. 15 & Agosto - Dezembro 2019 & p. $268-287$ \\
\hline
\end{tabular}


Foi nesse ambiente de gênese das paixões que o teatro, ou antes, a teatralidade pôde surgir, dando vida à metáfora do mundo como cena em um mesmo movimento responsável por criar a cisão entre o ser e o parecer. "Teatro", importa reforçar, não deve ser entendido aqui enquanto instituição, mas como chave de leitura para tentar entender o papel das paixões no quadro de desenvolvimento da sociedade. $\mathrm{O}$ homem natural, tal como é descrito hipoteticamente, pode ser compreendido como o ser a-teatral por excelência. Ele não possui nenhum recurso que não esteja ligado às suas capacidades físicas, enquanto o jogo cênico exige uma série de competências teóricas e cognitivas complexas. O homem natural também não faz uso da palavra quando a comunicabilidade da emoção por via oral, se não for imprescindível é ao menos importante para o espetáculo. Importa ainda notar que ele não faz guerra, não trama contra outros indivíduos, não sente ciúme, não ama, não possui a imaginação desenvolvida e não tem, enfim, ligações morais com outras pessoas. Sendo assim, não teria condições de se interessar pelo outro, o que é absolutamente fundamental para que qualquer espetáculo ou acontecimento desperte a atenção do auditório ou de uma testemunha. Os únicos sentimentos que estão presentes originalmente em sua composição são aqueles ligados às necessidades enquanto o teatro, de outro modo, é o reino da diversão ${ }^{4}$. O estreitamento dos laços pelo convívio social, a partir da ideia de emulação e de jogos de sedução excitou a noção de interesse particular e protagonismo social, exemplificado de maneira peculiar a cada sociedade:

Acostumaram-se a se reunir diante das cabanas ou ao redor de uma grande árvore; o canto e a dança, verdadeiros filhos do amor e do ócio [loisir], tornaram-se o divertimento [amusement] ou antes a ocupação dos homens e das mulheres ociosos e agrupados (ROUSSEAU, 1964, t. III, p. 169).

Essa descrição explicita em quais termos a teatralidade é essencial para a reflexão de Rousseau. Estão dispostos todos os elementos para fazer essa aproximação: o palco é ao ar livre, diante de uma cabana ou ao redor de uma grande árvore. Temos o representado, isto é, a música, a dança e as ideias primitivas de mérito e de beleza. Temos, igualmente, o representante, manifestado na figura do cantor ou dançarino. No

4 "Concluamos que, errando pelas florestas, sem indústria, sem palavra, sem domicílio, sem guerra e sem ligações, sem nenhuma necessidade dos seus semelhantes, como sem nenhum desejo de prejudicá-los, talvez até sem jamais reconhecer algum individualmente, o homem selvagem, sujeito a poucas paixões e bastando-se a si mesmo, possuía somente os sentimentos e as luzes próprias a esse estado, no qual possuía apenas suas verdadeiras necessidades (...) se por ventura realizava alguma descoberta, era tanto mais incapaz de a comunicar quanto nem mesmo reconhecia seus filhos (...) (ROUSSEAU, 1964, t. III, p. 159/160. Grifos meus).

\begin{tabular}{|l|l|l|l|l|}
\hline Q Rovista 2 ialectus & Ano 8 & n. 15 & Agosto-Dezembro 2019 & p. 268-287 \\
\hline
\end{tabular}


parágrafo 13 da Carta a d'Alembert o teatro é definido precisamente como 'amusement', mesma definição dada em 1755 a esse processo de estreitamento de laços e nascimento das paixões sociais ${ }^{5}$.

Continuemos acompanhando a descrição feita no Discurso sobre a desigualdade: "Cada um começou a olhar os outros e a querer ele mesmo ser visto, e assim a estima pública passou a ter um preço" (ROUSSEAU, 1964, t. III, p. 169). A noção de olhar está intimamente ligada à acepção latina da palavra “espetáculo" e, além disso, esse desejo de ser observado, de obter a estima pública, espécie de necessidade de protagonismo social indica, enfim, como esse referente teórico é importante. A gênese, portanto, do desejo de ser valorizado pode ser identificada no amor-próprio e descrita, precisamente, na forma de um indivíduo que se mostra ao olhar do outro. Esse processo não se dá exatamente como parte de um esforço pela conservação ou de maneira apenas indiferente, mas na forma de um ator que busca ganhar destaque nesse novo tipo de espetáculo: “Aquele que cantava melhor ou dançava melhor, o mais belo, o mais forte, o mais hábil ou o mais eloquente passou a ser mais considerado (...)" (ROUSSEAU, 1964, t. III, p. 169). A sociabilidade é inserida em um campo de atuações político-afetivas cuja descrição tem um claro tom teatral. O início hipotético do estreitamento das relações intersubjetivas parece pautado pelo estabelecimento de um acordo tácito constituído da seguinte maneira: se algum indivíduo apresentar certas características como ser belo, cantar bem, dançar melhor ou, no caso de uma sociedade cujo grau de complexidade já é grande, ter mais dinheiro, então, possuirá o direito moral de esperar ser recompensado com a valorização da sua pessoa.

Tais foram os artifícios criados para conseguir a admiração ou o enternecimento dos outros. Esse esquema teórico parece a caracterização do que no Manuscrito de Genebra é chamado de arte começada (1964, t. III, L. I, Cap. II, p. 288). Cantar, dançar, comparar-se e falar bem: termos ligados à arte, cuja conjugação passa a ser vinculada à admiração de outrem e que, ademais, corrobora ou mesmo inventa excitando a imaginação - uma desigualdade não natural instituída pela opinião. A caracterização feita por Rousseau da formação da sociedade no chamado segundo Discurso aponta para a artificialidade e contingência das instituições sociais: são frutos da convenção humana ou, se quisermos, da arte começada. Como é possível criar uma

5 No parágrafo 13 da Carta a d'Alembert, Rousseau afirma que "Lançando um primeiro olhar sobre essas instituições vejo primeiramente que um espetáculo é um divertimento" (ROUSSEAU, 1967, p. $65)$.

\begin{tabular}{|c|c|c|}
\hline Q Rovista Dialectus & Ano 8 & n. 15 \\
\hline
\end{tabular}


forma de governo que seja legítima é a tarefa proposta pelo Contrato social. Isso supõe, o que nos interessa particularmente, que a política seja, em última instância, uma forma de arte pois esse é o reino da técnica, da retórica e do artifício. Em uma palavra, âmbito de mediação dos interesses particulares.

A socialização como que inventa a cena teatral na medida em que cada indivíduo busca representar um papel, ou seja, se comporta de determinada maneira, ainda que seja por afetação, sempre na expectativa de ser aceito e valorizado. É um caso parecido com o do artista, pois ambos estão presos no conjunto de valores que são convencionalmente elencados como desejáveis: "Todo artista deseja ser aplaudido, e o elogio dos seus contemporâneos é sua recompensa mais preciosa." (ROUSSEAU, 1964, t. III, p. 21). Infeliz daquele que tenha nascido em um século corrompido, poderia dizer Rousseau, pois terá que se submeter necessariamente ao gosto do público. Temos um modelo que deve ser seguido, seja de beleza ou mérito, mas pode ser também uma vestimenta característica ou qualquer outra forma de luxo. O movimento inicial de socialização, descrito sintomaticamente como um espetáculo, pelo qual boa parte das paixões factícias aparecem é responsável, portanto, por alterar permanentemente a natureza humana, agora acrescida, podemos dizer, de novas afecções e desejos, tanto estéticos quanto morais, âmbitos que se entrelaçam.

Temos agora preferências, escolhas, comparações e desejos interesseiros. Conforme Rousseau, foi precisamente o comércio com a musas, conforme a metáfora usada no primeiro Discurso, uma das causas que fez as pessoas se tornarem sociáveis, excitando o desejo de se agradarem umas às outras, a partir de obras dignas de sua mútua aprovação (1964, t. III, p. 06). O surgimento da socialidade é inscrito então em uma atmosfera teatral, se confundindo com a aparição das belas artes como a canção, a dança e a poesia. Essas artes não necessárias, exatamente porque são contingentes, dão vazão a necessidades artificiais e a paixões factícias, no sentido preciso de não serem naturais. O indivíduo pertencente ao ambiente citadino, o burguês, com o amor-próprio dilatado, cuja felicidade passa pelo olhar do outro é identificado em mais de uma obra como "homem do homem" ". Esse indivíduo é distinto do que o indivíduo era (ou pôde ter sido) ao ter saído das mãos da natureza, entendida como o que corresponde ao âmbito originário, e é uma das variações possíveis pela qual as pessoas passam em nível

$6 \quad$ Ver, por exemplo, o Livro VIII das Confissões (1959, t. I, p. 388) e o Livro IV do Emílio (2004, p. $354)$.

\begin{tabular}{|c|c|c|}
\hline Q Rovista Dialectus & Ano 8 n & n. 15 \\
\hline
\end{tabular}


cultural. É assim que, como afirma Henri Gouhier, a história se opõe à natureza (2005, p. 12).

O homem do homem é conduzido por seu orgulho, vaidade e tende, além disso, a ser dissimulado porque está sempre em busca de ser bem quisto, de modo que fará de tudo para afetar as qualidades que lhe granjearão a aprovação dos outros. Para isso, age de maneira a encenar exatamente aquilo que pode agradar o seu público e o resultado, conforme Rousseau, é de suma importância, pois em busca de aprovação foi preciso se mostrar outro que não aquilo que se era realmente (1964, t. III, p. 174). Esse personagem egoísta, entediado e sempre em movimento é contraposto ao cidadão:

(...) tudo se reduzindo às aparências, tudo se torna artificial e representado [joué], seja a honra, a amizade, a virtude (...) perguntando sempre aos outros o que somos e não ousando jamais interrogarmo-nos a nós mesmos sobre isso, em meio a tanta filosofia (...) só temos um exterior enganador e frívolo (ROUSSEAU, 1964, t. III, p. 193).

A teatralidade sequestra o espaço da vida real. Tudo se reduz à aparência, tudo é artificial, representado e enganador: um simulacro se apresenta diante dos nossos olhos, um jogo de farsa é encenado em sociedade. A poesia dramática não funciona apenas como metáfora, mas também como registro a partir do qual se reflete sobre a sociedade. Não à toa o chamado homem do homem pode ser facilmente aproximado ao ator. Pergunta-se, com efeito, na Carta a d'Alembert, qual seria o talento do ator, "a arte de fingir, de revestir-se de um outro caráter que não o seu, de parecer diferente do que se é" (ROUSSEAU, 1967, p. 163). No Livro IV do Emílio o indivíduo enredado na aparência é compreendido como vivendo inteiramente em sua máscara (2004, p. 315). Como esquecer, ademais, o lamento indignado de Saint-Preux em relação aos parisienses na segunda Parte, Carta XIV, da Nova Heloísa: "Até aqui vi muitas máscaras, quando verei rostos de homens?" (ROUSSEAU, 1964, t. II, p. 236).

Assim como os dramaturgos, o indivíduo vaidoso deseja acima de tudo agradar o seu público. Cada pessoa passa a ser uma espécie de espetáculo para o outro, e isso em um sentido preciso que encontra eco na acepção latina da palavra "spectaculum", isto é, "aquilo que é visto". A festa primitiva que foi analisada por nós está longe de ser aquela de ordem cívica, na qual a unidade dos participantes é consolidada, tal qual apresentado no final da Carta a d'Alembert. Temos no primeiro caso, é verdade, uma agregação, mas não uma associação. Em outras palavras, temos uma reunião individualizante e não uma comunhão. Insisto no fato de que a reunião

\begin{tabular}{|l|l|l|l|l|}
\hline Q Povista Qialectus & Ano 8 & n. 15 & Agosto-Dezembro 2019 & p. 268-287 \\
\hline
\end{tabular}


com a qual se estreitam as relações intersubjetivas não forma um povo ou uma associação pautada pela obrigação política, capaz de criar um corpo moral. Trata-se, antes, de uma agregação, unidade fraca, individualizante e instável porque temos um ambiente no qual cada participante tenta trazer para si o protagonismo, tornando-se espetáculo em sentido puro, justamente por tentar capturar o olhar de outrem ${ }^{7}$. O resultado é o conflito indiscriminado, iniciado pela rivalidade e encerrado com a violência.

Vimos como o emprego frequente de elementos teatrais não se limita às metáforas ou exemplos eruditos. Não se trata apenas de uma figura de linguagem, já que se confunde com as possibilidades do discurso filosófico. De fato, é do interior do mundo da aparência, no palco do mundo de onde a figura do sábio, do filósofo ou do legislador pode surgir e atuar na política. Isso acontece porque é no registro social, de convenções, já marcado pelo afastamento da natureza onde a política se faz, tentando criar artificialmente, com a ajuda da arte aperfeiçoada, o liame social capaz de formar uma unidade fundamental responsável por dar legitimidade ao corpo político.

Acompanhando um enorme número de menções ao universo teatral, componentes do vocabulário filosófico de Rousseau, encontramos a utilização frequente de efeitos próprios ao teatro, como a ênfase, a grandiloquência, o conflito, o complô e também, usando uma expressão de Victor Goldschmidt, as "fórmulas surpreendentes" que o leitor, por vezes, é tentado a deslocar do seu contexto (1983, p. 11). Esses aspectos conferem à sua filosofia algo de sedutor e enganoso, caso as afirmações enfáticas não sejam compreendidas em consonância com os princípios teóricos ou, ainda, quando as suas concessões são tomadas como parte de sua posição. Tudo se passa como aponta a metáfora da natureza enquanto teatro mencionada anteriormente. No caso da filosofia rousseauniana, seria preciso enxergar o conjunto da obra e não apenas facetas de um fraseado intempestivo.

A autobiografia proposta por Rousseau, eis o que gostaria de expor agora, pode ser identificada a certa mise en scène. Uma das primeiras impressões da leitura das

7 A distinção conceitual entre associação e agregação é exposta no Capítulo V, Livro I do Contrato social (1964, t. III, p. 359). Essa questão é bem analisada por Bruno Bernardi no livro La fabrique des concepts: recherches sur l'invention conceptuelle chez Rousseau, mais especificamente na Primeira Partes, Association et agrégation (la médiation chimique) (2006, p. 49/75).

\begin{tabular}{|c|c|c|}
\hline Govista Qialeatus & Ano 8 & n. 1 \\
\hline
\end{tabular}


Confissões, ainda que isso não tenha sido objeto de muitos estudos é, precisamente, o caráter patético da descrição da personalidade e da vida de Rousseau. Entendo patético como o emprego de uma linguagem carregada de emoção, com um tom trágico e, por vezes, dramático, próximo do chamado drama burguês diderotiano, como tentarei defender. Rousseau pinta de si um retrato no qual a teatralização aparece não como mero mecanismo de camuflagem ou decoração, recurso do poeta, porém como o veículo privilegiado de explicitação do que podemos chamar de "personagem Rousseau". A mise en scène aqui evidenciada, como se esperaria, é altamente visual. Rousseau declara logo no início do Livro I, por exemplo, que se mostrará tal como ele foi e que desvelou seu interior (ROUSSEAU, 1959, t. I, p. 5). Afirmações como essas tornam o alvo de explicitação da obra, o próprio autor, um espetáculo eminentemente visual.

Philippe Lejeune define a autobiografia como um "relato retrospectivo em prosa que alguém faz de sua própria existência quando se coloca o acento principal sobre a vida do indivíduo, em particular sobre a história de sua personalidade" (LEJEUNE, 1975, p. 14). Se aplicarmos essa definição ao texto agora investigado, devemos associá-la a um ponto importante explicitado por Bronislaw Baczko quando afirma que as Confissões participam de um projeto de construção de um modelo filosófico e moral, mas também literário, da personalidade e de seu destino (1974, p. 164). Vou me concentrar na perspectiva literário-teatral e, se estiver correto, poderemos perceber como essa ideia de modelo natural se conjuga com o recurso tirado do teatro, essencialmente artificial.

Abordarei as Confissões e outros textos autobiográficos de Rousseau como obras filosófico-literárias, de modo que perguntar sobre a veracidade factual do relato perde sua importância primeira. Não pretendo, portanto, colocar em xeque os sentimentos descritos ou procurar uma razão de ordem psicológica para explicá-los. Se não interrogaremos o texto em seu aspecto factual é precisamente por ser possível encontrar autenticidade deixando de lado a precisão dos fatos, principalmente quando a memória afetiva é aquela responsável por conduzir o relato.

O que me interessa é acompanhar a articulação argumentativa de momentos emblemáticos para a compreensão da relação de Rousseau com o teatro e do seu vocabulário ligado a essa arte. Efetivamente, a percepção que ele tinha de si mesmo é altamente ligada a uma atmosfera teatral. Afinal de contas, estamos falando de um autor

\begin{tabular}{|c|c|c|}
\hline Q Rovista Dialectus & Ano 8 n & n. 15 \\
\hline
\end{tabular}


que afirma em diversas ocasiões que possui o espírito e uma curiosidade romanescas ${ }^{8}$. Mais do que isso, alguém cuja cabeça não saberia apenas embelezar as coisas, porém, criar (1959. t. I, L. IV, p. 171-172). A literatura e o teatro estão presentes na descrição de sua personalidade e forneceram a essa imaginação efervescente o veículo para canalizar sua energia criativa e filosófica. Rousseau pensa filosoficamente por meio do drama e ambienta a sua vida e os seus argumentos de modo igualmente dramático.

Qual saldo tiraremos desses apontamentos? Do ponto de vista do seu discurso, vemos a corroboração da ligação estreita com o registro teatral. Temos o tom elevado, mas também o acento dramático que reivindicam a uma só vez o ineditismo e a exclusividade. Esses são traços importantes e que, no caso das obras autobiográficas, conectam Rousseau ao universo da ribalta. Até mesmo coisas comuns, na letra do texto, se inserem em uma retórica da hipérbole e flertam com o extraordinário porque a descrição eleva Rousseau à categoria de único e ele conclama sem cessar sua exclusividade. Na segunda caminhada dos Devaneios de um caminhante solitário a ênfase na singularidade e o tom grandiloquente se mantêm: "tendo então formado o projeto de descrever o estado habitual da minha alma na mais estranha posição onde se possa encontrar um mortal” (ROUSSEAU, 1959, p. 1002).

O caráter singular do personagem construído pelas obras autobiográficas é constantemente afirmado e sua história, como a de toda tragédia, é orientada por um conflito fundamental contra o qual lutou sem sucesso, pois da maneira como o relato é conduzido seria o seu destino que exigiria satisfação. "Nasci enfermo e moribundo. Custei a vida à minha mãe e meu nascimento foi a primeira das minhas infelicidades” (ROUSSEAU, 1959, t. I, L. I, p. 7). Uma marca negativa, desde o início, o acompanha e interfere em sua vida. Quando comenta a respeito de uma época em que vivia em Paris,

8 No Livro I das Confissões (1959, t. I, p. 8), Rousseau diz ter formado em sua infância noções bizarras e romanescas da vida humana; na p. 17 do mesmo Livro I, ele afirma ter um espírito romanesco; na p. 77, agora já no Livro II, é mencionado como ele possuiria uma espécie de loucura romanesca da qual nunca pôde se curar; na p. 89, Livro III, o filósofo comenta como se vale, em certa oportunidade, de um expediente romanesco para se livrar de uma situação complicada. A referências continuam. Ainda no Livro III, p. 98, lê-se sobre os projetos chamados de romanescos; Livro IV, p. 158, repete-se a menção aos projetos romanescos. O autor identifica sua curiosidade como romanesca no Livro IV, p. 164. No Livro X, p. 543, afirma ter um espírito romanesco; no Livro XII, p. 640, declara ter traçado projetos romanescos. Em uma obra como a Carta a Malesherbes, mais precisamente na segunda carta, datada de 12\0111762, explica como “(...) com seis anos Plutarco tombou-me nas mãos, com oito eu o sabia de cor. Tinha ludo todos os romances, eles me fizeram derramar baldes de lágrimas antes da idade em que o coração se interessa por romances (...) daí se formou esse gosto heroico e romanesco que só aumentou até o presente" (ROUSSEAU, 1959, t. I, p. 1134). No que diz respeito à literatura secundária, quanto à relação de Rousseau com os romances, é incontornável o livro de Jean-Louis Lecercle, Rousseau et l'art du roman, de 1969. Sobre sua imaginação e personalidade romanescas, chamo atenção para o Capítulo I, chamado Une âme romanesque (1969, pp. 11-38).

\begin{tabular}{|c|c|c|}
\hline Govista Qialeatus & Ano 8 & n. 1 \\
\hline
\end{tabular}


antes de ganhar fama como escritor, ele diz que "assim começa em sua primeira origem a cadeia de minhas infelicidades" (ROUSSEAU, 1959, t. I, p. 549). Na sétima caminhada dos Devaneios lemos como sua sina seria a mais triste já vivida por algum mortal (1959, t. I, p. 1073).

No terceiro parágrafo do Livro I das Confissões, passagem de tom quase apocalíptico, momento no qual Rousseau afirma que entregaria essa obra para Deus no juízo final com a certeza de que estaria inteiramente justificado, o leitor acompanha com alguma surpresa a apóstrofe do filósofo genebrino ao Ser eterno. "Reúna ao redor de mim a inumerável multidão dos semelhantes: que eles gemam com minhas indignidades, que eles enrubesçam com minhas misérias”. (ROUSSEAU, 1959, t. I, p. 5). O que Rousseau faz aqui senão organizar o espetáculo de sua vida? Ao mestre de cerimônia, Deus ele mesmo, é sugerido que reúna o público. A audiência se emocionará e lançará gemidos, mas também se envergonharão diante do relato, em uma espécie de mistura de efeitos afetivos esperados, respectivamente, pela tragédia e pela comédia. Nessa mise en scèce estão presentes o acento hiperbólico, o trágico e o conflito: pontos basilares de sua narrativa e, sintomaticamente, características vinculadas estreitamente ao herói trágico do teatro clássico francês. Entretanto, ponto interessante para o qual devemos prestar atenção, Rousseau se mostra do ponto de vista social como uma pessoa comum, sem relevância política capital. A narrativa que ele propõe não se isenta de fazer uso de elementos excessivamente íntimos ou indecentes do ponto de vista da bienséance típica do teatro clássico. Esses aspectos baixos seriam mais apropriados à comédia ou, mais precisamente, ao drama tal qual proposto por Denis Diderot.

Não nos esqueçamos de que Rousseau se descreve como um "pobre herói” no Livro IV das Confissões (1959, t. I, p. 163), antonomásia importante porque reúne termos antitéticos. Cabe ressaltar que no teatro clássico o adjetivo "pobre", significando baixo, quando é colocado para acompanhar o substantivo "herói” associa termos normalmente separados. O herói trágico é uma figura cuja grandiosidade social ou política é latente e, mesmo se tem de enfrentar dificuldades terríveis, há sempre alguma pompa no seu discurso e comportamento. Sendo assim, o adjetivo dessa antonomásia parece deslocado quando pensamos em um herói nos moldes clássicos ${ }^{9}$.

$9 \quad$ Nas Réflexions critiques sur la poésie et sur la peinture, Jean-Baptiste Dubos, especificamente na seção XIV da primeira Parte, defende que o objetivo da tragédia é excitar terror e compaixão no espectador. O poeta, dessa forma, no caso de uma tragédia, apresenta ao público uma história cujo protagonista, de caráter valoroso e dotado de grandiosidade política ou social, se vê obrigado a

\begin{tabular}{|c|c|c|}
\hline Q Rovista Dialectus & Ano 8 & n. 15 \\
\hline
\end{tabular}


Contudo, o drama burguês defendido por Diderot, em textos como Conversas sobre o filho natural e o Discurso sobre a poesia dramática, tem como objetivo, em termos gerais, alçar o indivíduo comum a uma existência narrada com a ajuda de um tom sério, capaz de comportar gravidade. Eis uma estrutura na qual é possível acomodar perfeitamente a descrição feita por Rousseau de si mesmo.

A imagem do humano representada pelo protagonista da tragédia do teatro clássico era, sobretudo, de tipo aristocrática. O que Diderot tentou com o drama foi, repito, revestir de gravidade a existência também do burguês, alguém sem nobreza, sem uma família que o distinga dos demais, mas que não é ordinário porque possui mérito pessoal. Essa é parte importante do projeto rousseauniano. A importância do filósofo genebrino se liga aos seus sentimentos e ao que é desvelado por sua alma, e não a alguma posição social. Para Bronislaw Baczko, ele teria sido um dos primeiros a introduzir na literatura uma certa altivez (fierté) plebeia (1974, p. 155). É difícil corroborar essa afirmação sem um estudo exaustivo da produção literária universal, mas para nossos propósitos não importa tanto o aspecto inaugural do que a sua simples presença. Acrescento ser justamente em um flerte entre o grandioso e o baixo que pendula Jean-Jacques Rousseau, passando da "sublimidade do heroísmo à baixeza do vagabundo [vaurien]" (ROUSSEAU, 1959, t. I, L. I, p. 39).

Aparece diante de nós mais uma antítese que nos leva a pendular entre o grande e o baixo. Nas anotações do agente de polícia responsável pela censura editorial de Paris entre 1748 e 1753, Joseph d'Hémery, estudadas por Robert Darnton, Rousseau está listado entre os 'gens sans état', pessoas sem importância social que passavam de um emprego a outro sem muita estabilidade (1984, p. 5). Logo na Abertura do Livro I do Contrato social, lemos como Rousseau não teria importância sócio-política capital, pois não era nem príncipe nem legislador (1964, t. III, p. 351), ainda que fosse, à época, cidadão genebrino, algo capaz de revesti-lo com elevação e exclusividade. O ponto para o qual chamo atenção é o de que se funde no personagem autobiográfico o herói de duas tradições teatrais para quem a região da mediania não convém. Ele pode ser muito grandioso ou muito baixo, mas não ordinário: "Na ordem sucessiva de meus gostos e minhas ideias, fui sempre ou muito alto ou muito baixo. Aquiles ou Térsites, por vezes heróis, por vezes patife” (ROUSSEAU, 1959, t. I, L. III, p. 91). Aniquila-se, em certa medida o maniqueísmo do teatro clássico, ao menos o protagonista que vemos ser

enfrentar uma situação de infelicidade a partir, por exemplo, de uma dificuldade que precisa ser vencida. Isso causaria uma sensação de piedade e terror.

\begin{tabular}{|c|c|c|}
\hline Qonista Dialectus & Ano 8 & n. 1 \\
\hline
\end{tabular}


evidenciado não é alguém exclusivamente altivo ou baixo, porém, transita entre esses campos, participante de uma atmosfera do tipo realista no interior de um registro teatral. Rousseau, um herói: essa hipótese não daria vazão a uma compreensão equivocada do filósofo como uma pessoa transtornada que se considerava uma espécie de profeta de uma verdade até então inaudita? Não é meu objetivo fazer uma análise psiquiátrica, interessa-me muito mais compreendê-lo como figura literário-filosófica, com o objetivo de entender o seu vocabulário teatral e como ele se articula com a sua reflexão política e moral, ainda que neste texto não seja essa a questão pormenorizadamente tratada.

Saliento que a descrição que caracteriza o personagem autobiográfico não coloca em questão a legitimidade da obra teórico-filosófica, mas acredito que a complemente. Minha pretensão foi especialmente mostrar como o relato de si nas obras autobiográficas guarda aspectos com a ajuda dos quais podemos apontar o caráter intrinsecamente teatral de sua narrativa e recursos de escrita. Jean Starobinski comenta um ponto importante sobre o que chamei de mise em scène percebida nas Confissões, mais especificamente a respeito do comportamento teatral da descrição rousseauniana quando retoma algumas críticas dirigidas contra o projeto das Confissões:

Muitos críticos, a partir das declarações das Confissões, mostraram o aspecto teatral e forçado dessa conduta (...) se há desempenho teatral em tudo isso, é aquele que a sociologia pode descobrir em todo compromisso sério e deliberado (...)" (STAROBINSKI, 2011, p. 383).

De uma perspectiva metodológica, minha interpretação não aborda as afirmações das obras autobiográficas de modo a entendê-las como forçadas. Como poderíamos fazê-lo? "Forçadas", mas de que maneira? Se o factual não está necessariamente ligado à memória afetiva, se a apreensão que cada um faz de si mesmo dificilmente pode ser integralmente objetiva e, caso haja equívoco ou mesmo mentira, isso sinaliza menos uma farsa do que os traços fundamentais a partir dos quais uma personalidade se forma e se manifesta. Caso Rousseau, tal como se descreve, pinta um retrato capaz de aproximá-lo a algo como uma figura heroica a conclusão não deve ser a de que sua apreensão de si é forçada, mas a de que o teatro está estreitamente próximo de suas pretensões literárias e da abordagem em relação à sua experiência de vida. A justificação de Starobinski, segundo a qual as Confissões dizem respeito a um empreendimento sério ainda que seja um relato entremeado com elementos líricoteatrais não parece esclarecer completamente o que está em jogo.

\begin{tabular}{|c|c|c|c|c|}
\hline Q Rovista Dialectus & Ano 8 & n. 15 & Agosto - Dezembro 2019 & p. $268-287$ \\
\hline
\end{tabular}


Minha abordagem da autobiografia rousseauniana é a partir da pressuposição de que se trata de um trabalho literário-filosófico. Assim, para mim é de segunda importância perguntar pela verdade factual ou sinceridade, pois nem sempre o compromisso de uma obra literária é com os fatos em sua fixidez monótona. Principalmente se a narrativa está ligada um discurso que visa retraçar a memória afetiva, oscilante, de um autor hipersensível, interpretando momentos vividos tanto como o agente empírico quanto o escritor que descreve, embeleza e, sobretudo, cria. Nesse caso, pode haver autenticidade sem estar acompanhada de veracidade. Não se trata de uma escrita forçada, baseada em uma análise de tipo psicologizante, e nem de um discurso que se pretende completamente factual-descritivo, isto é, documental. O emprego do teatro tem justamente a complexidade de ser substancialmente ambivalente. Ele pode ser considerado uma arma corruptora capaz de intensificar a cisão entre ser e parecer ou, ainda, como um recurso para a desvelamento de si.

A linguagem das Confissões, altamente visual, que em mais de um momento aponta para o objetivo de mostrar Rousseau tal como foi faz parte de um projeto paradoxal que propõe um bom uso de algo que passou por um processo de degenerescência, ou seja, que contribuiu para a corrupção moral. Se a linguagem pode mascarar ou falsear, se ela participa de modo importante na cisão entre o ser e o parecer, enfim, ela também guarda em si "a pretensão de ser o lugar da expressão pura e de mais pura liberdade." (PRADO, 2008, p. 116). A música, mas também o teatro pode servir para manifestar um espetáculo positivo e de autenticidade. Lembremos que Rousseau afirma sobre o seu exemplo manifestado nas Confissões que ele não encontrará imitadores, todavia, Bento Prado Jr. já apontou a ironia contida nessa espécie de desafio, pois um exemplo sempre pressupõe um modelo e a possibilidade de que alguém o reproduza (2008, p. 104).

O panorama pela teatralidade em Rousseau tem uma importante serventia. É preciso que estejamos atentos ao modo pelo qual a ligação do autor com o universo teatral é essencialmente estreita, mesmo intrínseca. O resultado a que se chega não é tanto o de marcar a frequência das menções ao teatro, seja para mostrar a sua existência quanto para defender a sua relevância, coisa que todo leitor atento pode perceber, mas, principalmente, chamar a atenção para algo talvez mais interessante: indicar como não se trata apenas de metáforas, empregadas como parte de um arsenal de figuras de linguagem. Rousseau claramente ilustra sua personalidade de modo teatral e se vale desse recurso quando vai tratar de posições mais teóricas.

\begin{tabular}{|c|c|c|c|c|}
\hline Q Rovista Dialectus & Ano 8 & n. 15 & Agosto - Dezembro 2019 & p. $268-287$ \\
\hline
\end{tabular}


Vimos, efetivamente, como o âmbito da política e das relações sociais também são abordados por esse registro. Ao fim e ao cabo, o campo lexical de onde emana a abordagem filosófica de Rousseau está essencialmente vinculado ao teatro. Esse elemento pode ser usado positiva ou negativamente, sempre a depender das circunstâncias. No caso das Confissões, nunca se tratou de desvelar uma verdade integralmente factual, mas sim uma verdade mais geral, de ordem moral, tentando extrair com a sua ajuda uma lição útil, tal como se fosse um conto ou uma fábula, como vemos na quarta Caminhada dos Devaneios de um caminhante solitário (1959, t. I, p. 1033). Tudo se passa como se a obra se fundisse com o autor, ou seja, como se ela fosse a sua emanação: são as Confissões que Rousseau diz que serão apresentadas a Deus no juízo final precisamente como testemunha principal de sua defesa. São elas que dirão o que ele fez, o que pensou e o que ele foi. O espetáculo já não será um baile de máscaras, porém, como diz a epígrafe em latim das Confissões, intus et in cute, será um espetáculo a partir de onde se revela o interior e o que se esconde sob a pele. A linguagem teatralizada agora concorre para o desvelamento e não encobrimento.

O teatro é como que alçado a um reino arquetípico, a uma categoria a partir da qual Rousseau pensa sua personalidade, mas também, como vimos, a constituição da vida social e a política. Quanto ao teatro, não temos diante de nós um conceito cuja complexidade deve ser analisada exclusivamente em busca do que podemos chamar de definição. O uso do teatro é por demais amplo para ser assimilado a um conceito unívoco, temos antes um registro ou uma noção no interior da qual é possível compreender parte importante do pensamento de Rousseau. Como afirma Luiz Roberto Salinas Fortes, autor que esteve sempre no horizonte das notas aqui apresentadas:

A história é efetivamente palco e peça e é condição de possibilidade de todo espetáculo (...) os homens são atores. No palco sócio-político se desenrola um interminável combate trágico, uma tragicomédia de dissimulação e revelações (...) na medida em que escreve, Rousseau não foge desta condição. É certo que visa combater o disfarce e denunciar a dissimulação, mas não pode renunciar ao teatro, teatralizando sua própria vida. (FORTES, 1997, p. 98).

\section{REFERÊNCIAS :}

BACZKO, B. Rousseau: solitude et communauté. Paris: École Pratique des Hautes Études et Mouton \& Co, 1974.

BERNARDI, B. La fabrique des concepts : recherches sur l'invention conceptuelle chez Rousseau. Paris: Honoré Champion, 2006.

\begin{tabular}{|c|c|c|}
\hline Q Rovista Dialectus & Ano 8 & n. 1 \\
\hline
\end{tabular}


DARNTON, R. Policing writers in Paris circa 1750. In: Representations, University of California Press, $N^{\circ}$ 5, 1984, 1-31.

DIDEROT, D. Entretiens sur le fils naturel - De la poésie dramatique - Paradoxe sur le comédien. Paris: Flammarion, 2005.

FONTENELle, B. Entretiens sur La Pluralité des Mondes. Paris: Chez Michel Brunet, 1724.

FORTES, L. R. S. Dos jogos de teatro no pensamento pedagógico e político de Rousseau. In: Revista Discurso. Nº10, São Paulo, 1979, 79-85.

FORTE, L. R. S. Paradoxo do Espetáculo: Política e Poética em Rousseau. São Paulo: FAPESP, 1997.

GOLDSCHMIDT. V. Anthropologie et politique: les principes du système de Rousseau. Paris: VRIN, 1983.

JR., B. P. A retórica de Rousseau. São Paulo: COSAC NAIFY, 2008.

LECERCLE, J.-L. Rousseau et l'art du roman. Genebra: Slatkine Reprints, 1979.

LEJEUNE, P. Le pacte autobiographique. Paris: Édition du Seuil, 1975.

STAROBINSKI, J. Jean-Jacques Rousseau: a transparência e o obstáculo. Trad. Maria Lúcia Machado. São Paulo: Companhia das Letras, 2011.

ROUSSEAU, J.-J. Carta a Malesherbes. In: Carta a Christophe de Beaumont e outros escritos sobre a religião e a moral. Org. MARQUES, J. São Paulo: Editora Estação liberdade, 2005.

ROUSSEAU, J-J. Correspondance complète de Jean-Jacques Rousseau. Org. R. A. Leigh. Tomo V - 1758. Genebra: DROZ, 1967.

ROUSSEAU, J.-J. Discours sur les sciences et les arts. In: Oeuvres complètes. Tomo III. Org. Bernard Gagnebin et Marcel Raymond. Paris: Pléiade, 1964.

\begin{tabular}{|c|c|c|c|c|}
\hline Qenista Dialectus & Ano 8 & n. 15 & Agosto - Dezembro 2019 & p. $268-287$ \\
\hline
\end{tabular}


ROUSSEAU, J.-J. Discours sur l'origine et les fondements de l'inegalité parmi les hommes. In: Oeuvres complètes. Tomo III. Org. Bernard Gagnebin et Marcel Raymond. Paris: Pléiade, 1964.

ROUSSEAU, J.-J. Emílio ou da Educação. $4^{\circ}$ Edição. Trad. Roberto Leal Ferreira. São Paulo: Martins Fontes, 2004.

ROUSSEAU, J.-J. Ensaio sobre a origem das línguas. Trad. Fulvia M. L. Moretto.Campinas: Ed. UNICAMP, 2008.

ROUSSEAU, J.-J. Fragments autobiographiques et documents biographiques. In: Oeuvres complètes. Tomo I. Paris: Pléiade, 1959.

ROUSSEAU, J.-J. Institutions chimiques. Texto estabelecido por Bruno Bernardi e Bernadette Bensaude-Vincenta. Paris: Arthème Fayard, 1999.

ROUSSEAU, J.-J. La Nouvelle Helö̈se. In: Oeuvres Complètes. Tomo II. Dijon: Gallimard, 1964.

ROUSSEAU, J.-J. Les confessions. In: Oeuvres complètes. Tomo I. Paris: Pléiade, 1959.

ROUSSEAU, J.-J. Les rêveries du promeneur solitaire. In: Oeuvres complètes. Les confessions. Autres textes autobiographiques. Tomo I. Paris: Pléiade, 1959.

ROUSSEAU, J-J. Lettre à d'Alembert sur les spectacles. Apresentação de Michel Launay. Paris: Flammarion, 1967.

VOLTAIRE. Essai sur les moeurs. In: Oeuvres complètes de Voltaire. Tomo III. Paris: Chez Lefèvre Libraire, 1818.

\begin{tabular}{|l|l|l|l|l|}
\hline Q Povista Dialectus & Ano 8 & n. 15 & Agosto - Dezembro 2019 & p. 268-287 \\
\hline
\end{tabular}

